\title{
PENGARUH MOTIVASI DAN SIKAP TERHADAP LOYALITAS KONSUMEN PADA STUDIO JONAS PHOTO
}

\author{
Yupi Yuliawati \\ Universitas Islam Nusantara \\ yupiyuliawati@gmail.com
}

\begin{abstract}
This study aimed to determine the effect of motivation and attitude towards customer loyalty Jonas photo studio. The research method used is descriptive verification. The findings stated motivations and attitudes affect the loyalty simultaneously and partially
\end{abstract}

Keywords: Motivation, Attitude, Customer Loyalty

\section{PENDAHULUAN}

Seiring perkembangan jaman, fotografi berkembang pesat dalam era globalisasi. Tak jarang pula, seseorang mengabadikan bagian hidupnya dengan mendapatkan kesan mendalam terhadap dirinya, keluarga, teman ataupun orang lain. Kejadiankejadian penting dalam hidup yang dapat terlewatkan dengan bertambahnya usia dapat diabadikan dengan sebuah foto. Bisnis jasa fotografi dalam satu dekade terakhir mendapatkan tantangan yang dahsyat akibat berkembangnya teknologi digital dan semakin banyaknya ponsel pintar yang punya kemampuan memotret dan menyimpan. Tak urung, banyak gerai jasa fotografi diberbagai kota di Indonesia gulung tikar. Sebuah data menyebutkan, sebelum tahun 2000, terdapat tak kurang dari 4000 toko foto di Indonesia, dan ketika terjadi peralihan teknologi dari analog ke digital hanya tersisa 1000-an toko foto. Ribuan toko mati karena bisnis cetak foto sudah kehilangan zaman. Tantangan itu juga dirasakan oleh Jonas Photo pelaku jasa fotografi terbesar di Bandung yang cukup terkenal. Sejumlah inovasi dilakukan untuk menyelamatkan bisnis Jonas Photo untuk menghadapi perubahan yang bergerak cepat salah satunya membeli mesin digital foto, printing, jonas juga melakukan inovasi pada bisnis studio dan ritel. Tidak heran sebagian orang menganggap Jonas sebagai one stop solution. Saat ini Jonas Photo sedang mengembangkan inegrasi konsep gerai fotografi dengan resto dan gerai fashion. perkembangan ponsel pintar dengan dukungan kualitas foto yang bagus, tidak memberi dampak yang negatif bagi pelaku usaha jasa fotografi di Indonesia. Potensi dan peluangnya masih terbuka lebar di tengah perkembangan digital yang pesat.(www.swa.co.id)

Jonas photo dan Papyrus photo merupakan dua studio photo terkenal di Bandung. Kedua studio photo ini memiliki konsumen yang loyal. Berdasarkan hasil pra penelitian yang penulis lakukan, sebagian besar responden memang lebih memilih Jonas Photo karena sudah lebih dikenal brandnya terlebih dahulu dibandingkan Papyrus, harga lebih terjangkau, dan positioningnya sudah kuat ketika ditanya photo studio mereka menjawab Jonas Photo. Sebagian lagi menjawab Papyrus yang memiliki ruangan lebih luas, dan tema-tema nya lebih banyak, walaupun memang harganya lebih mahal dibandingkan dengan Jonas Photo. Berdasarkan latar belakang diatas, penulis tertarik untuk meneliti "pengaruh motivasi dan sikap terhadap loyalitas konsumen pada studio Jonas photo".

\section{KAJIAN PUSTAKA}

Schiffman dan Kanuk (2008) mendefinisikan motivasi "motivation can be described as driving force within individuals that impels them to action. This Driving force is produced by state of tension, which exist as the result of unfufilled need. Mowen dan Minor dalam Ujang Suwarman (2002) motivations refers to the processes that cause people behave as they do. It occurs when a need is aroused that cause that the consumer wishes satisfy. Once a need has been activated, a state of exists that drives the consumer to attempt to reduce or eliminate the need. Ujang Suwarman (2002) motivasi muncul karena adanya kebutuhan yang dirasakan oleh konsumen. Kebutuhan sendiri muncul karena konsumen merasakan ketidaknyamanan (state of tension) antara yang seharusnya dirasakan dan sesungguhnya yang dirasakan. Kebutuhan yang dirasakan tersebut mendrong seseorang untuk melakukan tindakan memenuhi kebutuhan tersebut. Inilah yang disebut dengan motivasi. Motivasi dapat digambarkan sebagai tenaga pendorong dalam diri individu yang memaksa untuk bertindak. Motivasi adalah dorongan dari dalam individu untuk memenuhi suatu kebutuhan yang tidak terpenuhi yang memaksa mereka untuk bertindak sehingga seseorang berupaya untuk memenuhinya (Schiffman \& Kanuk, 2008:71). Motivasi adalah kemampuan untuk berbuat sesuatu sedangkan motif adalah kebutuhan, keinginan, dorongan untuk berbuat sesuatu. Motivasi seseorang di pengaruhi oleh stimuli kekuatan intrinsik yang ada pada individu yang bersangkutan. Stimuli eksternal mungkin dapat pula mempengaruhi motivasi itu sendiri mencerminkan reaksi individu terhadap stimuli tersebut. Semua individu mempunyai kebutuhan, hasrat, dan keinginan. Kebutuhan dari seseorang tidak pernah terpuaskan, kebutuhan individu seringkali tidak disadari oleh yang bersangkutan. Timbulnya serangkaian kebutuhan khusus pada waktu tertentu mungkin disebabkan oleh rangsangan yang terdapat di dalam kondisi fisiologis, oleh proses emosi atau kesadaran, atau oleh rangsangan yang berasal dari lingkungan diluar dirinya. a. Fisiologis Kebutuhan fisiologis merupakan kebutuhan manusia tingkat 
pertama dan paling dasar. Kebutuhan dasar yaitu kebutuhan yang dibawa sejak individu lahir meliputi faktor yang dibutuhkan untuk menopang kebutuhan hidup seperti makanan, air, pakaian, rumah, dan lainlain. (Schiffman \& Kanuk, 2008: ).b. Emosional "Motif Emosional mengandung arti bahwa pemilihan sasarannya menurut kriteria pribadi atau subyektif, seperti kebanggaan, ketakutan, kasih sayang, atau status. Diasumsikan bahwa para konsumen selalu berusaha memilih berbagai alternatifyang menurut pandangan mereka membantu memaksimumkan kepuasan" (Schiffman \& Kanuk, 2008). c. Lingkungan yaitu Serangkaian kebutuhan yang dialami orang pada waktu tertentu sering dihidupkan oleh berbagai syarat khusus di lingkungannya. "Jika orang hidup di lingkungan yang kompleks dan sangat bervariasi, mereka akan mengalami berbagai kemungkinan yang memicu kebutuhan. Sebaliknya, jika lingkungan mereka miskin atau serba kekurangan, lebih sedikit kebutuhan yang timbul" (Schiffman \& Kanuk, 2008)

Ujang Suwarma (2002) sikap (attitudes) konsumen adalah faktor penting yang akan mempengaruhi keputusan konsumen. Konsep sikap sangat terkait dengan konsep kepercayaan (belief) dan perilaku (behavior). Mowen dan minor (1995) menyebutkan bahwa istilah pembentukan sikap konsumen seringkali menggambarkan hubungan antara kepercayaan, sikap, dan perilaku. Kepercayaan, sikap, dan perilaku juga terkait dengan konsep atribut produk Sikap (Attitudes) konsumen adalah faktor penting yang akan mempengaruhi keputusan konsumen. Konsep sikap sangat terkait dengan konsep kepercayaan (belief) dan perilaku (behavior). Sikap merupakan ungkapan perasaan konsumen tentang suatu objek apakah disukai atau tidak, dan sikap juga bisa menggambarkan kepercayaan konsumen terhadap berbagai atribut dan manfaat dari objek tersebut. Kepercayaan konsumen adalah pengetahuan konsumen mengenai suatu objek, atributnya, dan manfaatnya. Kepercayaan, sikap, dan perilaku juga terkait dengan konsep atribut produk (product attribute). Atribut produk adalah karakteristik dari suatu produk. Konsumen biasanya memiliki kepercayaan terhadap atribut suatu produk. (Ujang,Suwarman,2002). Sedangkan menurut Menurut Tricomponent Attitude Model ( Schiffman \& Kanuk, 2008; dan Engel, Blackwell, dan Miniard, 1995), sikap terdiri atas tiga komponen : Kognitif (Pengetahuan), Afektif (Emosi), dan Konatif (Tindakan). Sikap terdiri dari tiga komponen yaitu komponen kognitif, afektif, dan konatif atau bisa kita kenal dengan model ABC (Afektif = perasaan), Behavior Intention $(\mathrm{B}=$ keinginan $)$, dan komponen Cognitive $(\mathrm{C}=$ kognisi). Komponen kognitif berhubungan dengan hal-hal yang diketahui individu atau pengalaman individu baik yang sifatnya langsung atau tidak langsung dengan obyek sikap. Komponen afektif berhubungan dengan perasaan dan emosi konsumen mengenai obyek sikap. Komponen afektif ini dapat beragam ekspresinya mulai dari rasa tidak suka atau sangat tidak senang. Komponen konatif berkenaan dengan obyek sikap, komponen ini masih berupa keinginan untuk melakukan suatu tindakan. (Tatik Suryani, 2013)
Menurut Tjiptono (2007) loyalitas konsumen adalah komitmen pelanggan terhadap suatu merek, toko atau pemasok berdasarkan sifat yang sangat positif dalam pembelian jangka panjang. Dari pengertian ini dapat diartikan bahwa kesetiaan terhadap merek diperoleh karena adanya kombinasi dari kepuasan dan keluhan. Sedangkan kepuasan pelanggan tersebut hadir dari seberapa besar kinerja perusahaan untuk menimbulkan kepuasan tersebut dengan meminimalkan keluhan sehingga diperoleh pembelian jangka panjang yang dilakukan oleh konsumen. Loyalitas pelanggan sangat penting artinya bagi perusahaan yang menjaga kelangsungan usahanya maupun kelangsungan kegiatan usahanya. Pelanggan yang setia adalah mereka yang sangat puas dengan produk dan pelayanan tertentu, sehingga mempunyai antusiasme untuk memperkenalkannya kepada siapapun yang mereka kenal. Selanjutnya pada tahap berikutnya pelanggan yang loyal tersebut akan memperluas "kesetiaan" mereka pada produk-produk lain buatan produsen yang sama. Dan pada akhirnya mereka adalah konsumen yang setia pada produsen atau perusahaan tertentu untuk selamanya.

Konsumen yang loyal terhadap suatu merek adalah konsumen yang menyatakan sangat menyukai merek tersebut dan kemudian membeli dan menggunakan merek tersebut. Loyalitas merek akan menyebabkan munculkan komitmen merek, yaitu kedekatan emosional dan psikologis dari seorang konsumen terhadap suatu produk. Philip Kotler (2007) menyatakan bahwa loyalitas tinggi adalah pelanggan yang melakukan pembelian dengan prosentasi makin meningkat pada perusahaan tertentu daripada perusahaan lain. Dalam upaya untuk mempertahankan pelanggan harus mendapatkan prioritas yang lebih besar dibandingkan untuk mendapatkan pelanggan baru. Oleh karena itu, loyalitas pelanggan berdasarkan kepuasan murni dan terus-menerus merupakan salah satu aset terbesar yang mungkin didapat oleh perusahaan.

Terdapat beberapa aspek yang mempengaruhi loyalitas tamu. Menurut Zikmund dalam Vanessa (2007:72) loyalitas pelanggan dipengaruhi oleh lima faktor yaitu : 1. Satisfaction (kepuasan). Kepuasan pelanggan merupakan perbandingan antara harapan sebelum melakukan pembelian dengan kinerja yang dirasakan. 2. Emotional bonding (ikatan emosi) Dimana konsumen dapat terpengaruh oleh sebuah merek yang memiliki daya tarik tersendiri sehingga konsumen dapat diidentifikasikan dalam sebuah merek, karena sebuah merek dapat mencerminkan karakteristik konsumen tersebut. Ikatan yang tercipta dari sebuah merek ialah ketika konsumen merasakan ikatan yang kuat dengan konsumen lain yang menggunakan produk atau jasa yang sama. 3. Trust (kepercayaan) Kemauan seseorang untuk mempercayakan perusahaan atau sebuah merek untuk melakukan tau menjalankan sebuah fungsi. 4. Choice reduction and habit (kemudahan) Jika konsumen akan merasa nyaman dengan sebuah merek kerika situasi mereka melakukan transaksi memberikan kemudahan. Bagian dari loyalitas konsumen seperti pembelian produk secara teratur dapat didasari pada akumulasi pengalaman setiap saat. 5. History with company (pengalaman dengan perusahaan) Sebuah pengalaman seseorang pada perusahaan dapat 
membentuk perilaku. Ketika kita mendapatkan pelayanan yang baik dari perusahaan, maka kita akan mengulangi perilaku kita pada perusahaan tersebut.

Kelima faktor di atas, dapat membentuk loyalitas pelanggan yang didasari perspektif sikap dan perilaku. Loyalitas pelanggan yang didasari perspektif sikap dipengaruhi oleh ketiga faktor pertama, sedangkan loyalitas yang didasari perspektif perilaku dipengaruhi oleh kedua hal lainnya. Menurut Kotler dan Keller (2007), loyalitas konsumen didefinisikan sebagai sebuah komitmen yang dipegang teguh untuk membeli kembali atau menggunakan produk atau opsi layanan di masa mendatang meskipun pengaruh situasi dan upaya pemasaran memiliki potensi untuk menyebabkan terjadinya perubahan perilaku Menurut Griffin (2005), indikator konsumen yang loyal terhadap suatu produk atau jasa, yaitu: 1. Melakukan pembelian secara teratur (Makes regular repeat purchase). 2. Pembelian antar lini produk atau jasa (Purchases Across product and service lines.) 3. Mereferensikan ke orang lain (Refers others). 4. Menunjukkan kekebalan dari tarikan persaingan (tidak mudah terpengaruh oleh tarikan persaingan produk sejenis lainnya/ Demonstrates in immunity to the pull of the competition).

Sikap positif terhadap produk tertentu akan memungkinkan konsumen melakukan pembelian ulang. Sebaliknya sikap negatif akan menghalangi konsumen untuk membeli lagi (Sutisna, 2001). Menurut Kotler (2005) terdapat dua faktor yang mempengaruhi seseorang dalam pembelian kembali, yaitu situasi tidak terduga (Unexpected situation) dan sikap khalayak. Menurut Tjiptono (2008) loyalitas merupakan komitmen palanggan terhadap toko, merk ataupun pemasok yang didasarkan atas sikap positif yang tercermin dalam bentuk pembelian berulang secara konsisten. berdasarkan kerangka pemikiran diatas bahwa dapat kita ketahui motivasi dan sikap berpengaruh terhadap loyalitas konsumen.
Gambar 1 Paradigma Penelitian

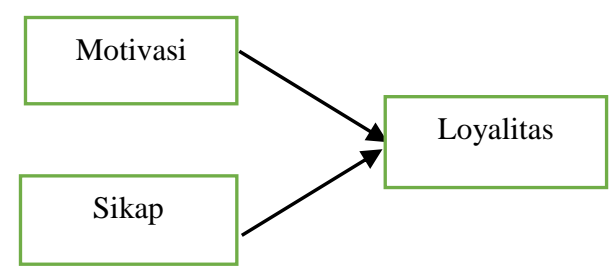

\section{METODE PENELITIAN}

Penelitian ini dilakukan untuk mengetahui pengaruh pengaruh motivasi dan sikap terhadap loyalitas konsumen Jonas Photo. Variabel bebas (independent variable) yang terdapat pada penelitian ini yaitu Motivasi dan sikap sedangkan variabel terikat (dependent variable) yaitu loyalitas . Motivasi dengan dimensi kenyamanan, harga, kualitas produk sedangkan Sikap dengan deimensi kepercayaan, atribut, emosi, perasaan, dan kecendrungan. Dimensi loyalitas yaitu Pembelian ulang, pembelian luar lini produk, rekomendasi, kekebalan dari produk dari pesaing

Objek/unit analisis pada penelitian ini yaitu konsumen Jonas Photo di Bandung. Teknik yang digunakan dalam penelitian ini adalah teknik propability yaitu simple random dengan jumlah sampel sebanyak 120 konsumen. Teknik pengumpulan data yang digunakan adalah studi kepustakaan, studi lapangan dengan penyebaran kuesioner, dan studi literatur. Sedangkan teknik analisis data yang dilakukan adalah analisis deskriptif dan verifikatif. Analisis data verifikatif menggunakan regresi linier bantuan software SPSS 23 for windows.

\section{HASIL PENELITIAN DAN PEMBAHASAN}

Tabel 1 ANOVA

\begin{tabular}{|c|c|c|c|c|c|}
\hline Model & $\begin{array}{l}\text { Sum of } \\
\text { Squares }\end{array}$ & $\mathrm{df}$ & $\begin{array}{l}\text { Mean } \\
\text { Square }\end{array}$ & $\mathrm{F}$ & Sig. \\
\hline 1 Regression & 77,433 & 2 & 38,717 & 11,227 &, $000^{b}$ \\
\hline Residual & 403,492 & 117 & 3,449 & & \\
\hline Total & 480,925 & 119 & & & \\
\hline
\end{tabular}

a. Dependent Variable: Loyalitas 
b. Predictors: (Constant), Sikap, Motivasi

\begin{tabular}{|l|l|l|l|l|l|}
\hline \multicolumn{6}{|c|}{ Tabel 2 Model Summary } \\
\hline Model & $\mathrm{R}$ & $\begin{array}{l}\mathrm{R} \\
\text { Square }\end{array}$ & $\begin{array}{l}\text { Adjusted } \\
\text { Square }\end{array}$ & $\begin{array}{l}\text { Std. Error of the } \\
\text { Estimate }\end{array}$ & $\begin{array}{l}\text { Durbin- } \\
\text { Watson }\end{array}$ \\
\hline 1 &, $401^{\mathrm{a}}$ &, 161 &, 147 & 1,857 & 1,507 \\
\hline
\end{tabular}

Tabel 3 Coefficients ${ }^{\mathrm{a}}$

\begin{tabular}{|c|c|c|c|c|c|c|c|}
\hline \multirow[b]{2}{*}{ Model } & \multicolumn{2}{|c|}{$\begin{array}{l}\text { Unstandar- } \\
\text { dized } \\
\text { Coefficients }\end{array}$} & \multirow{2}{*}{$\begin{array}{l}\text { Standar- } \\
\text { dized } \\
\text { Coeffi } \\
\text { cients } \\
\text { Beta }\end{array}$} & \multirow[b]{2}{*}{$\mathrm{t}$} & \multirow[b]{2}{*}{ Sig. } & \multicolumn{2}{|c|}{$\begin{array}{l}\text { Collinearity } \\
\text { Statistics }\end{array}$} \\
\hline & B & $\begin{array}{l}\text { Std. } \\
\text { Error }\end{array}$ & & & & $\begin{array}{l}\text { Tole } \\
\text { rance }\end{array}$ & VIF \\
\hline \multirow{3}{*}{\begin{tabular}{l|l|} 
& (Constant) \\
& Motivasi \\
& Sikap \\
\end{tabular}} & 9,617 & 1,827 & & 5,264 &, 000 & & \\
\hline &, 324 &, 117 &, 238 & 2,779 & ,006 & ,974 & 1,026 \\
\hline &, 259 &, 077 & 287 & 3,344 & ,001 & ,974 & 1,026 \\
\hline
\end{tabular}

Pengujian hipotesis dalam penelitian ini dilakukan untuk mengetahui besarnya pengaruh pengaruh motivasi dan sikap terhadap loyalitas. Pengujian hipotesis secara simultan dilakukan menggunakan teknik analisis regresi linier. Hipotesis penelitian ini adalah motivasi dan sikap berpengaruh secara simultan dan parsial terhadap loyalitas konsumen. Hipotesis ini diuji secara simultan maupun parsial dengan menggunakan SPSS 23 for windows. Hasil pengujian hipotesis secara keseluruhan (simultan) dapat dilihat berdasarkan vaariabel motivasi dan sikap memiliki pengaruh langsung terhadap loyalitas sebesar Secara simultan motivasi dan sikap berpengaruh nyata terhadap loyalitas hal ini ditunjukkan oleh nilai signifikansi $(0,0000<\alpha(0,05)$ maka $\mathrm{H}_{0}$ ditolak (hipotesis penelitian diterima). (lihat tabel 1). Secara bersama-sama pengaruh variabel motivasi dan sikap terhadap loyalitas sebesar 16,1 persen, hal ini menginformasikan bahwa loyalitas konsumen tidak hanya dipengaruhi oleh motivasi dan sikap. (lihat tabel 2). Setiap peningkatan 10 satuan skor motivasi akan meningkatkan loyalitas sebesar 32,4 skor loyalitas konsumen. Setiap peningkatan 10 satuan skor sikap akan meningkatkan 25,9 skor loyalitas konsumen. Konstanta sebesar 9,617 menunjukkan besarnya skor loyalitas konsumen apabila skor motivasi dan sikap masing-masing 0 (lihat tabel 3).

Hasil penelitian menunjukkan bahwa motivasi dan sikap berpengaruh terhadap loyalitas konsumen. Pengaruh motivasi dan sikap memang tidak terlalu besar terhadap loyalitas konsumen, banyak faktor lain yang mempengaruhi seperti kepuasan, harga, kualitas layanan, kepercayaan, kemudahan, pengalaman degan perusahaan yang bisa dijadikan penelitian selanjutnya.

\section{DAFTAR PUSTAKA}

Gaffar, Vanessa. (2007). CRM dan MPR Hotel. Alfabeta: Bandung.

Griffin, Jill. (2005). Customer Loyalty. Jakarta: Erlangga.

Kotler, Keller. (2007). Manajemen Pemasaran. Jakarta: Indeks

Kotler, Phillip dan Gary Amstrong, 2008, Prinsip-Prinsip Pemasaran, Jilid 1, edisi keduabelas, jakarta: Erlangga

Schifman, Leon G dan Kanuk, Leslie. 2008. Prilaku Konsumen edisi ketujuh: Edisi ketujuh. Jakarta: Indeks

Suwarman, Ujang. (2002). Perilaku Konsumen. Bogor : Ghalia Indoneia

Suryani,Tatik. (2013). Perilaku Konsumen di Era Internet. Yogyakarta: Graha Ilmu.

Tjiptono, Fandi dkk. (2008). Pemasaran Stratejik. Yogyakarta: Andi.

www.serbabandung.com/studio-foto/ www.wisatabdg.com/2015/07/jonas-photomaju-dan-berkembang-di.html?m=1 www.swa.co.id/swa/profile/profilrcompany/arif-hadikusuma-melanggengkankejayaan-jonas-photo www.swa.co.id/supaya-bisnis-jasa-fotografitetap-bertahan 